\title{
현장조사와 침투모형시험을 통한 방조제 침투특성 연구 A Study on the Characteristics of Infiltration of Sea Dyke by Field Investigation and Seepage Model Test
}

\author{
박춘식* · 김종환** - 이선일*** \\ Choon Sik Park*, Jong Hwan Kim** and Sun Il Lee***
}

\begin{abstract}
요 지 : 본 연구는 다층지반으로 구성된 방조제의 침투변화에 따른 안정성을 검토하기 위하여 현장조사와 역해석 방 법으로 투수계수와 침투수량을 결정하고, 제체의 변형량과 유실량 측정을 위하여 침투모형시험을 수행하여 가장 합 리적인 수치해석 방법을 결정하였다. 검토결과 방조제는 다층지반구조물로 투수계수 차이에 의해 바닥보호공과 성 토체 경계부에서 유실이 발생하고 이로 인해 방조제의 변형이 발생한다는 것을 예측할 수 있었다. 한편 침투모형 시험에 대한 수치해석결과 한계유속에 의한 방법은 실측치가 해석값보다 작게 나왔으나 그 경향이 유사하여 실제 단면에 적용 가능할 것으로 판단되었다.
\end{abstract}

핵심용어 : 방조제, 침투변화, 침투모형시험, 투수계수, 한계유속

\begin{abstract}
The purpose of this study is to decide the permeability and the rate of flow in a way of both site investigation and backward analysis and the most reasonable numerical analysis by performing a seepage model test for measuring the deformation swept volume of the embankment body in order to review a stability of the sea dyke being composed of multi-layers depending on variation of infiltration. As a result of the review, it could be forecasted that sweeping loss would be taken place at the boundary between bed protection works and embankment materials of the sea dyke due to a permeability difference of the multi-layered bed foundation structures and the sea dyke deformation would be occurred as a result thereby. As result of a numerical analysis for the seepage model test, it could be observed that critical velocity method was found to be smaller than the numerical analysis value but its tendency was similar and therefore it was judged that this method could be applied for the actual cross section.
\end{abstract}

Keywords : sea dyke, variation of infiltration, seepage model test, permeability, critical velocity

\section{1. 서 론}

최근 연안해역에 대규모 단면으로 축조된 방조제는 방조제 단면을 통한 해수침투가 상당히 많이 발생되지만 현재는 이 에 대한 조사 및 안정성을 적절하게 평가할 수 있는 방법이 없는 상황으로 해수침투 변화로 인한 장기적인 방조제 안정 성 평가가 가능하고 이를 유지관리하는 단계에서 실무적으로 예측할 수 있는 기법개발이 필요한 실정이다.

본 연구와 관련하여 해수 침투에 대한 방조제의 안정성 평 가를 위해 정상상태의 수위조건에 대한 방조제에 대한 유한 요소해석을 농림수산부와 농어촌진흥공사(1990)와 허(1996) 가 실시한바 있다. 오(1997)는 정상상태와 비정상상태에 대 한 결과를 비교하였으며, 정(2002)은 비정상 상태의 침투해석 을 통하여 불포화 흐름을 고려한 비정상해석을 수행하였다.
또한 일반적인 파이핑에 대한 안정성 검토는 Terazaghi (1943), Kalin(1977), Schmertamann(2000)에 의한 한계동수 경사에 의한 방법, Richardson and Meikle(1961), Kovacs (1981), Sughii et al.(1989) 등에 의해 한계유속에 의한 방법 에 대하여 연구되어졌고, Hansen(1992), Stephenson (1979), 최 등(2004)의 여러 학자들에 의해 사석층에서의 물의 흐름 에 대한 침투특성 연구가 이루어져 왔다. 하지만 지금까지의 연구는 현장조사 및 실내시험 등의 방법에 의한 결과의 확인 이 어려운 상황이므로 그 적용성의 적정성을 판단하기 곤란 하였다.

따라서 본 연구는 성토재료가 투수성이 크고 침식에 약한 준설해사로 끝막이 구간의 바닥보호공이 해측과 내측으로 연 결되어 있어 침투량에 대한 충분한 검토가 요구되어지며, 장 기적인 방조제의 안정성에 대한 평가가 필요한 다층지반으로

\footnotetext{
* 창원대학교 토목공학과 교수(Choonsik Park, Depart. of Civil Eng., Changwon National Univ.)

** 창원 대학교 토목공학과, 공학박사(Corresponding author: Depart. of Civil Eng., Changwon National Univ., Sarimdong 9, Changwon, Gyeongnam 641-773, Korea. gypsyis@nate.com)

*** 한국농어촌공사, 공학박사(Korea Rural Community Corporation)
} 
구성된 방조제의 침투변화에 따른 안정성을 검토하기 위하여 현장조사와 현장계측을 통해 바닥보호공의 침투특성을 파악 하였다. 또한 침투모형시험의 방조제 제체 변형분석을 실시 하였으며, 한계동수경사, 한계유속, 유한요소 연계해석에 의 한 제체변형해석을 검토하여 실제단면에 적용할 수 있는 합 리적인 수치해석 방법을 도출하였다.

\section{2. 현장 조사}

Fig. 1과 같이 본 연구대상인 새만금 방조제는 세계 최대, 최장의 심해 방조제이며, 특히 끝막이 $2.7 \mathrm{~km}$ 구간은 사석끝 막이 공정의 효율적 수행을 위하여 바닥보호공을 내측까지 연 장하여, 준설해사로 충전이 된다하여도 상대적으로 투수성이 큰 사석층이 해측과 내측으로 연결되어 있는 조건이다. 본 연 구에서는 2호 방조제 끝막이 구간인 GAP 1 구간과 GAP 2 구간을 연구대상 구간으로 선정하였고, 유속조사, 색소추적자 조사, 공내촬영(BIPS, televiewer)을 실시하였고, 일정한 간격

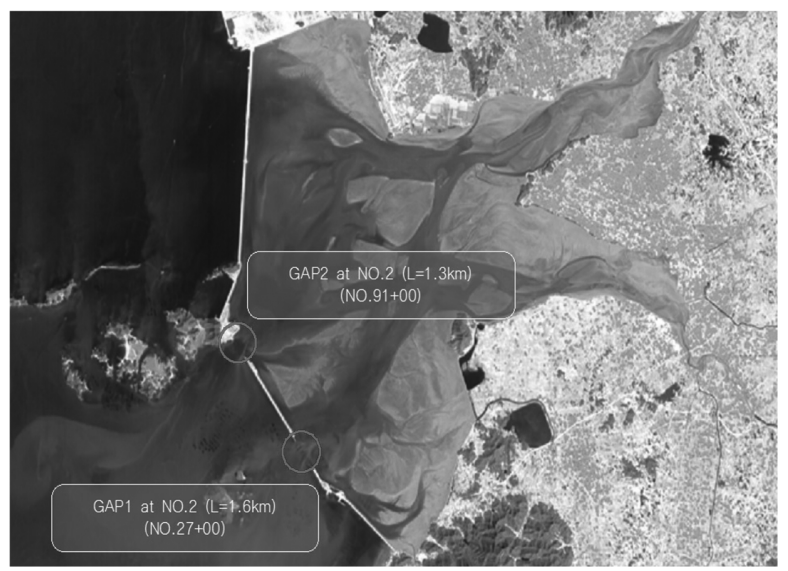

Fig. 1. Location of embankment.
에 대하여 현장계측을 실시하였다. Fig. 2에 GAP 1구간과 GAP 2구간의 단면을 나타내었다.

\section{1 현장조사 결과}

유속조사는 GAP 1구간에 대해서 실시하였고, 유속조사 결과, 와류구간의 평균유속은 약 $0.08 \mathrm{~m} / \mathrm{sec}$, 전체 총 바닥보 호공 평균유속은 $0.04 \mathrm{~m} / \mathrm{sec}$ 로 나타났으며, 바닥보호공내에 조 위변화에 따른 흐름이 발생하고 있는 것으로 나타났다.

GAP 1구간의 시험공 2곳, GAP 2구간의 시험공 1곳에 대 한 색소 추적자 조사 결과, GAP 1구간은 수용성의 색소가 일 정구간 준설해사로 충전된 바닥보호공내에서 희석되어서 색소 추적자 주입후 호측에서 색소가 검출되지 않았으며, GAP 2 구간은 바닥보호공내 불규칙한 방사형 유로로 주입된 색소 손 실이 발생하여 바닥보호공내에서 이동하지 못하고 머물러 있 는 것으로 나타났다.

Fig. 3 과 같이 공내촬영 결과, GAP 1 구간의 상부층은 대 부분 입자를 구분하기 어려울 정도의 세립질의 모래, 하부층 은 입자를 구분할 수 있는 중조립이나 조립질의 모래로 밀실 하게 충전되어 있는 상태로 파악되었으며, GAP 2구간은 사 석이 파악된 구간 $(31.0 \sim 32.0 \mathrm{~m}, 32.5 \sim 33.5 \mathrm{~m})$ 을 제외한 대부 분 입자를 구분하기 어려울 정도의 세립질의 모래로 구성되 어 있는 것으로 나타났다. 또한 이 구간 일부와 공동으로 파 악된 구간은 세립질의 모래가 채워져 있지 않은 충전이 불량 한 구간으로 조사되었다.

\section{2 현장 계측 결과}

끝막이 구간 바닥보호공 침투특성 분석을 위한 계측은 일 정거리 $(25.0 \mathrm{~m})$ 를 두고 바닥보호공내에 천공 및 간극수압계 를 매설하여 해내측 수위변화에 따른 바닥보호공내 간극수압 을 측정하였다. 수집된 각 위치별 계측자료를 바탕으로 1차

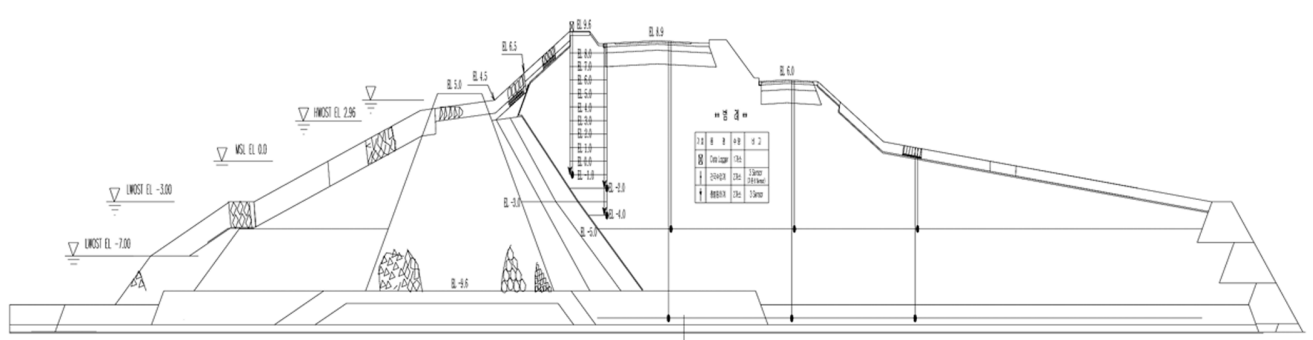

(a) GAP 1 section

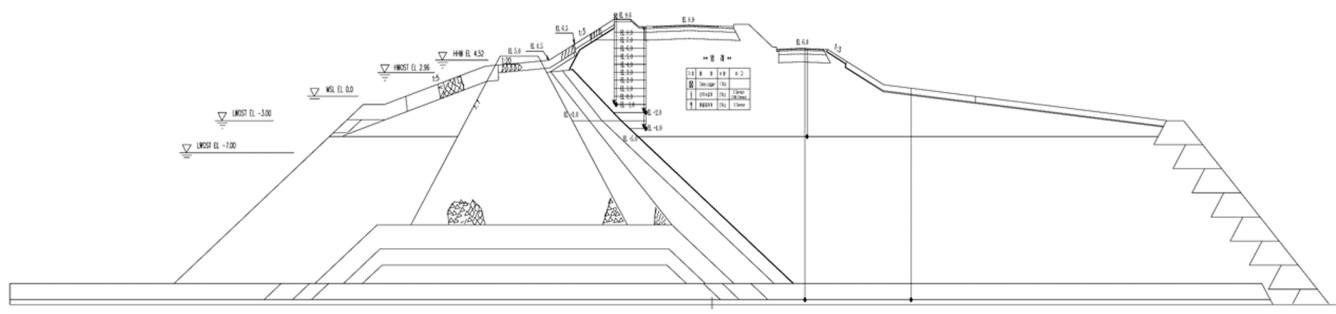

(b) GAP 2 section

Fig. 2. Cross section of embankment. 


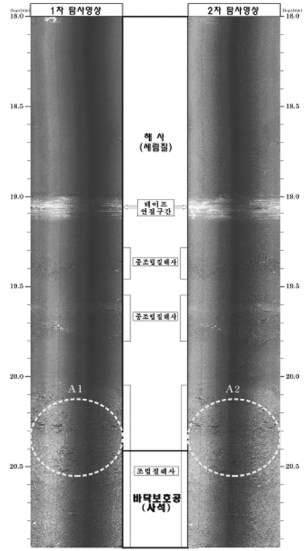

GAP 1

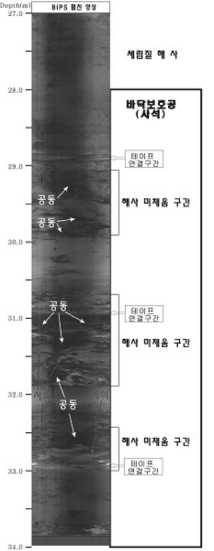

GAP 2

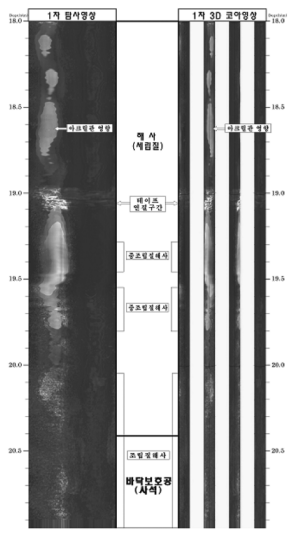

GAP 1

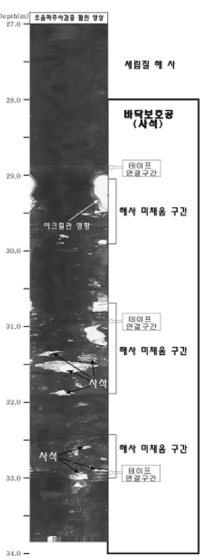

GAP 2

(a) BIPS

(b) Televiewer

Fig. 3. Results of borehole image shooting.

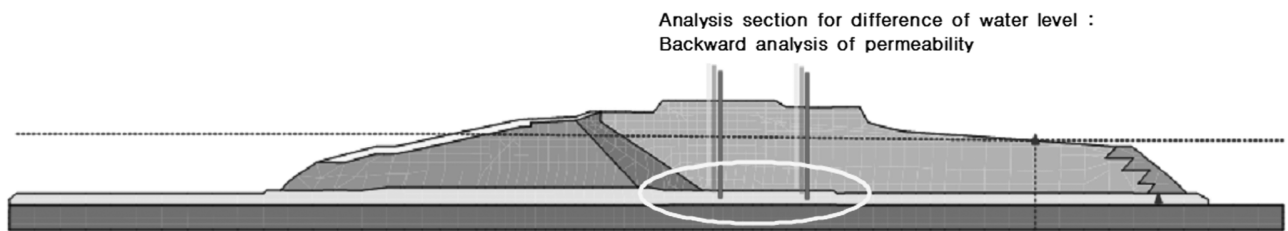

Fig. 4. Backward analysis section of GAP 1.

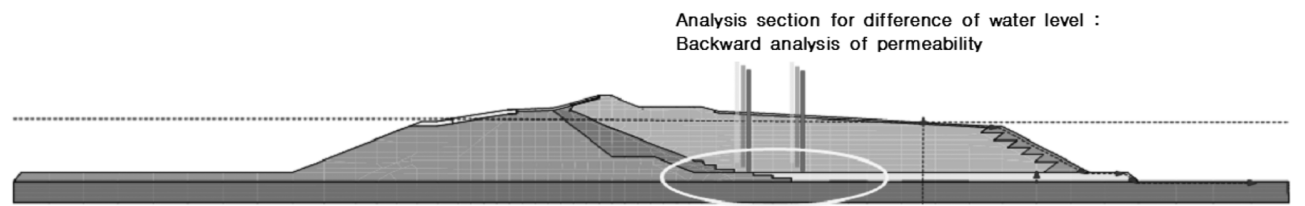

Fig. 5. Backward analysis section of GAP 2 .

적으로 정성적인 침투특성을 분석하였고, 각 위치의 침투로 인한 수위차 변화를 분석하여 바닥보호공의 침투특성을 평가 하였다.

GAP 1구간의 계측결과, 조위변화에 따른 해측 바닥보호공 (PPT 1)과 호측 바닥보호공(PPT 2)의 수위차 $(\Delta \mathrm{h})$ 변화가 조위 변화에 따라 거의 일정한 주기와 진폭으로 발생되고 있으며, 수위차는 간조시 최대 약 $1.4 \mathrm{~m}$ 까지 수두 진폭이 발생하였다. GAP 2구간은 조위변화에 따른 해측 바닥보호공(PPT 1)과 호 측 바닥보호공(PPT 2)의 수위차가 거의 없이 일정하며, 만조 시 $0.19 \mathrm{~m}$, 간조시 최대 $0.13 \mathrm{~m}$ 의 수두차가 발생하였다. 위 와 같은 결과로부터 GAP 2구간은 GAP 1구간에 비하여 끝 막이 바닥보호공의 수심이 깊어 준설 성토량도 많으며, 시공 조건도 양호하지 못하여 상대적으로 준설해사 충전이 용이하 게 이루어지지 않았으며, 특히 바닥보호공 및 상고공이 두꺼 워 준설해사의 충전이 원활하지 못하였을 것으로 판단되었다.

\section{3 역해석에 의한 바닥보호공 투수계수 산정}

끝막이 후 방조제 단면의 바닥보호공 투수계수 산정을 위 한 역해석 방법은 조위변동에 따른 각 계측지점의 수두손실 을 정수(constant)로 설정하고, 다양한 변수변화를 통한 시행착
오법으로 시산적용 후 역해석 변수(바닥보호공의 투수계수, 시공시 발생 가능한 지형변화 고려)를 결정 후, 각 계측공의 바닥보호공내 수두손실 계측결과를 활용하였다. 역해석 단면 은 Fig. 4와 Fig. 5와 같다.

\subsubsection{GAP 1구간의 해석결과}

Fig. 4의 해석단면에 대해서 바닥보호공 및 근고공의 투수

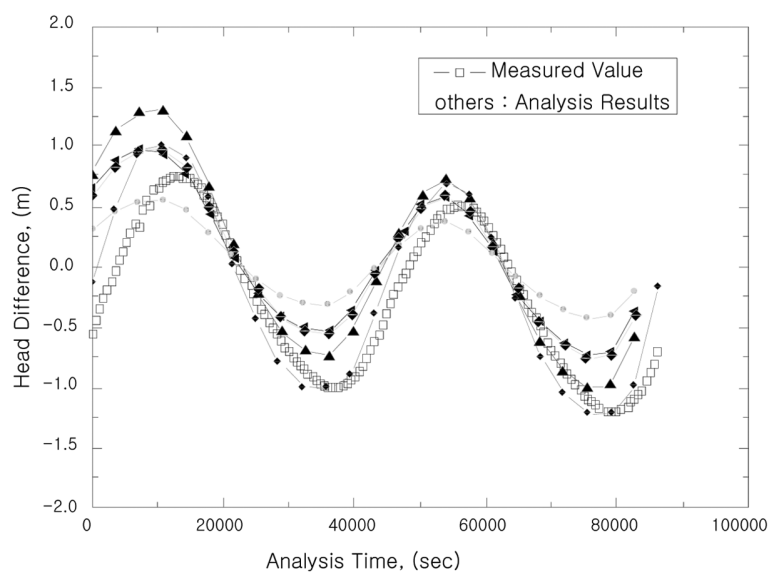

Fig. 6. Backward analysis result for permeability (GAP 1). 


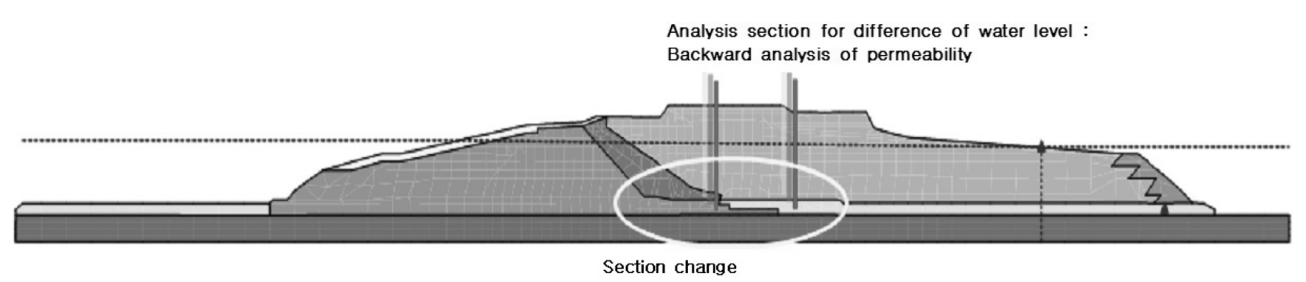

Fig. 7. Backward analysis modification section of GAP 1 .

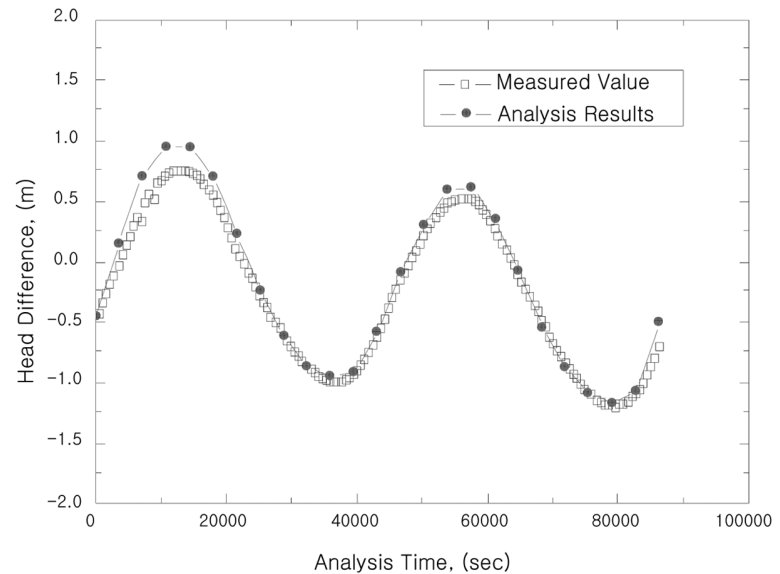

Fig. 8. Backward analysis result for difference of water head of modification section (GAP 1).

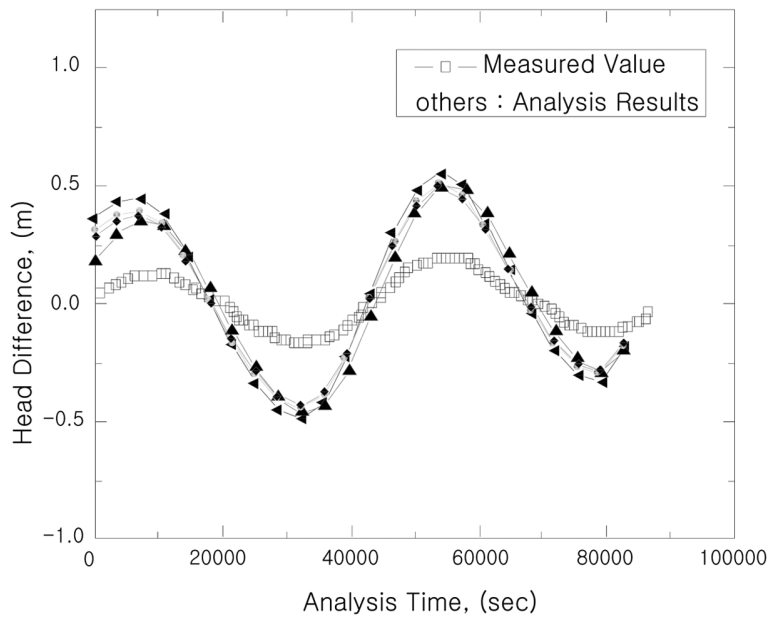

Fig. 9. Backward analysis result for permeability (GAP 2).

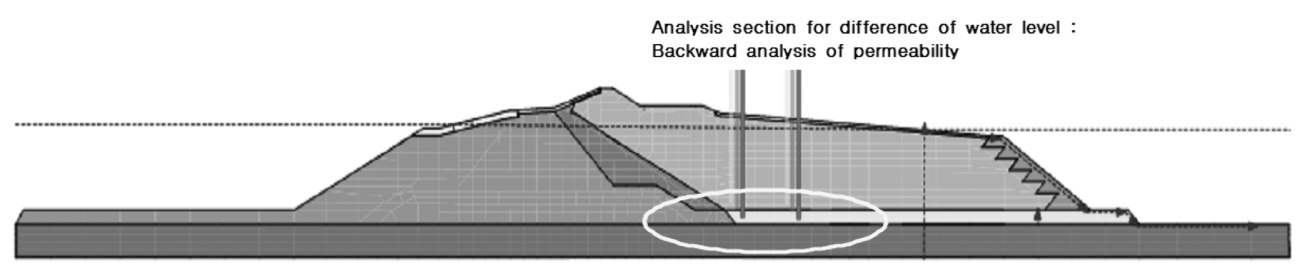

Fig. 10. Backward analysis modification section of GAP 2.

계수 변화를 1 100배 차이까지 역해석한 결과, Fig. 6과 같 이 투수계수의 변화와 관계없이 실계측 수두차와 큰 차이를 보였다. 따라서 설계단면상에 균질하게 바닥보호공이 시공 및 충전되었을 조건에서는 실제 계측된 수두손실을 역해석하기 불 가능하므로 시공단면에 대하여 Fig. 7과 같이 수정을 하였다. 수정해석 단면은 시공시 발생 가능한 단면을 가정하여 수정 하였고, 해측 바닥보호공 및 1 차 사석단면 하부의 바닥보호 공의 투수계수를 1 차 사석단면의 투수계수와 동일하게 적용 하였다.

역해석 수정단면 Fig. 7에 대한 해석결과, 1차 사석단면 및 근고공의 투수계수 $1.0 \times 10^{-3} \mathrm{~m} / \mathrm{sec}$, 바닥보호공의 투수계수 가 $7.6 \times 10^{-6} \mathrm{~m} / \mathrm{sec}$ 일 때 Fig. 8과 같이 실측된 손실수두와 거의 근접한 해석결과를 얻을 수 있었다.

\subsubsection{GAP 2구간의 해석결과}

Fig. 5의 해석단면에 대해서 바닥보호공의 투수계수변화를 $1 \sim 100$ 배 차이까지 해석한 결과, Fig. 9와 같이 투수계수의 변 화와 관계없이 실측계측 수두차(호측 바닥보호공/해측 바닥 보호공)와 큰 차이를 보여 시공단면에 대해서 Fig. 10과 같

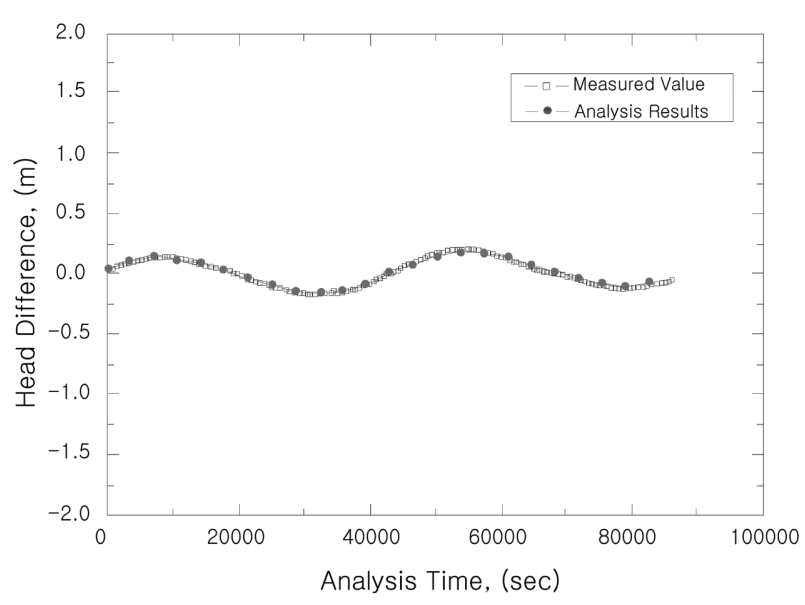

Fig. 11. Backward analysis result for difference of water head of modification section (GAP 2).

이 수정을 하였다. 수정한 단면은 시공시 발생 가능한 단면 을 가정하였고, 1 차 사석단면 하부의 바닥보호공의 투수계수 를 1 차 사석단면의 투수계수와 동일하게 적용하였으며, 바닥 보호공의 투수계수를 토석재료의 일반적 범위를 벗어나 유로 가 형성된 조건을 고려한 투수계수를 적용하였다. 
역해석 수정단면 Fig. 11에 대한 해석결과는 Fig. 12에 나타 내었다. 1 차 사석단면 및 근고공의 투수계수 $1.0 \times 10^{-4} \mathrm{~m} / \mathrm{sec}$, 바닥보호공의 투수계수를 $1.0 \times 10^{-2} \mathrm{~m} / \mathrm{sec}$ 일 때 실측된 손실 수두와 거의 근접한 해석결과를 얻을 수 있었다.

\section{3. 방조제 끝막이 구간의 침투특성}

현실적으로 복합재료로 축조되는 방조제의 사석단면 및 바 닥보호공과 같이, 규격석 및 대석으로 바닥보호공 및 1 차 사 석단면이 축조된 후, 준설매립을 통하여 사석재료의 공극이 작은 입자로 채워지는 복합재료의 경우, 정량적으로 정확한 투수특성을 평가하는 것은 기술적 어려움과 공학적 판단이 상당히 요구되는 과정이다. 또한, 공학적 판단에 복합적으 로 작용하는 과정은 방조제의 불확실한 축조형상을 들 수 있다.

바닥보호공의 축조 및 준설충전은 심해간척에서 이루어지 는 시공공정이며, 현장여건에 따라 불가피하게 단면형상 및 구성성상이 설계단면과 달라질 수 있다. 앞서 바닥보호공의 투수계수 역해석 과정에서 보는 바와 같이, 시공과정을 고려 한 단면형상 및 구성성상에 따른 투수성 변화를 고려하지 않 을 경우, 현장상태의 투수특성을 예측하는 것이 불가능함을 의미한다.

본 연구대상 방조제는 GAP 1, GAP 2 구간의 최종 끝막 이가 완료됨에 따라, 안정된 상태를 유지하던 방조제 내에 급 격하게 수위변화가 발생되고 내측 호수의 수위변화에 따라 방 조제 내에 투수특성이 변화한 것으로 판단되었다. 또한 최종 끝막이 이후 방조제 끝막이 구간의 침투특성은 끝막이 시공 과정 및 준설성토 단면조건에 따라 GAP 1 구간 및 GAP 2 구간에서 상이한 결과를 보이고 있다. GAP 1 구간 투수계수 는 사석재료 및 근고공의 경우 $1.0 \times 10^{-3} \mathrm{~m} / \mathrm{sec}$, 바닥보호공 의 경우 $7.6 \times 10^{-6} \mathrm{~m} / \mathrm{sec}$ 로 역해석 되었고, GAP 2 구간은 사 석재료 및 근고공의 투수계수가 $1.0 \times 10^{-3} \mathrm{~m} / \mathrm{sec}$, 바닥보호공 의 경우는 $1.0 \times 10^{-2} \mathrm{~m} / \mathrm{sec}$ 로 바닥보호공은 통수상태조건의 투수특성을 보이고 있다. 이러한 결과는 GAP 1구간이 GAP 2 구간에 비하여 바닥보호공 수심이 얕으며, 준설성토 시공조
건이 양호하고, 심도가 얕아 준설성토가 순차적으로 시공되 었기 때문에 나타난 결과라 할 수 있다.

\section{4. 침투모형시험}

방조제 바닥보호공에서 준설해사의 충전여부와 조위변화에 따른 유실여부를 실내실험에서 검증하기 위해 전체 바닥보호 공과 준설해사로 성토된 방조제 구간의 일부분을 구획화하여 바닥보호공내에서의 준설해사 충전 및 유실에 대한 침투모형 시험을 실시하였다. 본 연구에서 수행된 실내모형시험에서는 상사법칙을 이용한 방조제 단면 모사 및 동수경사 제어를 통 한 실시간 조위변화를 모사하였고, 초기 조건변화에 따른 침 투 유실율을 제시하여 표면고 변화로부터 제체 변위량을 측 정하였다. 또한 바닥보호공내의 토사 충전성 여부를 파악하 고 침강조로부터 토사 유실량을 정량적으로 측정하여 수위변 동에 따른 제체 변형량을 예측하여 실무적으로 예측할 수 있 는 방조제 안정성 해석기법을 제시하고자 하였다. 침투모형 시험에 사용된 준설 해사는 실트분이 함유된 균등한 입도를 가진 세립질 모래(SM)를 사용하였다.

\section{1 침투모형시험 범위 및 조건}

본 연구의 침투모형시험은 $\mathrm{GAP} 1$ 구간의 전체 방조제의 거 동을 반영할 수 있는 한계구간을 선정하였다. 모사될 방조제 경계구간은 Fig. 12 와 같이 방조제 가로길이는 약 $25 \mathrm{~m}$ 이 고 높이는 약 $21.5 \mathrm{~m}$ 이다. 특히 모사된 구역의 경계는 향후 조위차에 의한 준설해사의 충전 및 유실경향을 쉽게 파악할 수 있도록 실측수두가 관측된 PPT 1지점과 PPT 2지점의 위 치와 동일하게 선정하였다.

\subsection{1 침투모형시험 장치}

침투모형시험기는 동수경사와 조위차 등 다양한 영향인자 하에서 실시간으로 모형 방조제의 거동을 관찰하기 위해 총 3가지의 영역(모형토조, 수두조절장치 및 방조제 거동분석용 계측기)으로 분리하여 제작하였으며, Table 1에 세부적으로 나 타내었다.

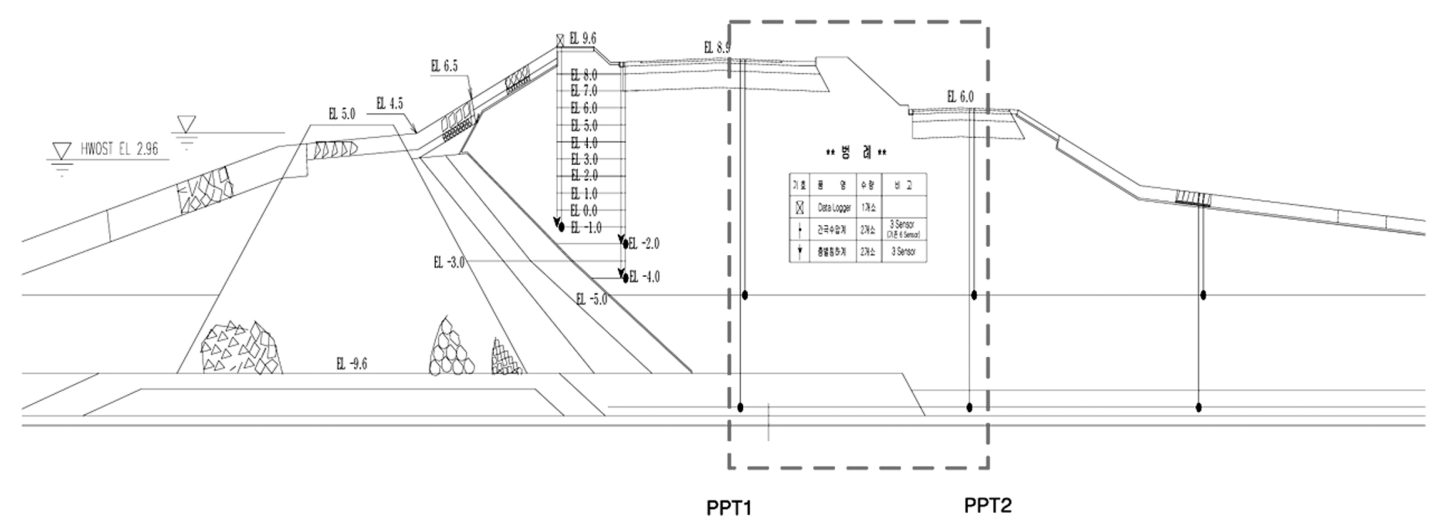

Fig. 12. Section of seepage model test. 
Table 1. Detail composition of seepage model tester

Model tester

Table 2. Actual water level and similitude water level of seepage model tester

\begin{tabular}{|c|c|c|c|c|}
\hline & \multirow{2}{*}{ Location } & \multicolumn{2}{|c|}{ Elevation } & \multirow{2}{*}{ Note } \\
\hline & & Actual water level (m) & Water level of Model tester (mm) & \\
\hline \multirow{2}{*}{ High Tide } & PPT 1 & E.L(+) 2.8 & E.L(+) 112 & \multirow{4}{*}{$1 / 25$ downscale } \\
\hline & РPT 2 & E.L $(+) 2.0$ & E.L(+) 80 & \\
\hline \multirow{2}{*}{ Low tide } & PPT 1 & E.L(-) 2.0 & E.L( $(-) 80$ & \\
\hline & PPT 2 & E.L(-) 1.0 & E.L(-) 40 & \\
\hline
\end{tabular}

\section{1 .2 수두 경계조건}

수두 경계조건은 외측과 내측의 조위변화에 따라 PPT 1지 점과 PPT 2지점에서 실시간으로 계측된 데이터 값을 기본으 로 경계조건을 설정하였다. Table 2에 조위변화에 따른 침투 모형토조에서의 수두변화 경향을 나타내었다.

\subsection{3 침투모형시험 세부조건}

침투모형시험은 침투 유실에 의한 제체의 변형을 분석하기 위하여 수위 경계변화에 따라서 침윤선 형성조건, 현재 수위 조건, 향후 관리수위 조건(갈수위 고려)으로 나누어 실험을 수 행하였고, 침투압에 의한 토사의 침강 및 소류현상을 관찰하 고 바닥보호공내로 충전된 토립자의 이동이 유발되는 한계동 수경사를 도출하기 위해서 12 시간 간격으로 내측과 외측의 수 두차 $(\Delta \mathrm{h})$ 를 $0.5 \mathrm{~cm}$ 씩 증가시키며, 그에 따른 제체의 변위와 바닥보호공에서의 유실량을 정량적으로 측정하였고, 조위변 화에 따른 해수면이 상승과 하강을 반복될 경우, 조위차에 의 한 해수의 반복적 침투거동에 따른 방조제 제체변형의 안정 성을 검토하기 위해 매 6 시간 간격으로 만조 $(\mathrm{EL} .=+3.2 \mathrm{~cm})$ 와 간조 $(\mathrm{EL} .=-4.0 \mathrm{~cm})$ 상태의 수위차를 반복적으로 변화하 여 현재수위 조건(내측 $\mathrm{EL} .=0 \mathrm{~cm})$, 향후 관리수위 조건(내 측 EL. $=-1.5 \mathrm{~cm})$, 향후 최저수위 조건 $($ 내측 $\mathrm{EL} .=-2.0 \mathrm{~cm}$ ) 으로 나누어 실험을 수행하였다.

\section{2 침투모형시험 결과}

4.2.1 수위 경계 변화에 따른 방조제 제체 변형

수위 경계변화에 따른 방조제 제체 변형 실험을 수행한 결과, 동수경사가 발생하지 않도록 내측과 외측의 수두를 동 일하게 유지하여 제체 내 침윤선이 형성되고 변위량이 수렴 하는 안정화 단계까지 총 270 분이 경과하였으며, 이 때의 제
체 변위는 Fig. 13과 같이 초기에 급격히 진행되는 경향을 나 타내었다.

Fig. 14에서 수위조건별 초기 변위량을 비교하면 현재수위 및 향후 관리수위 조건에서 제체의 변위는 480 분 이후에 급 격히 변화됨을 알 수 있다. 현재수위 조건에서 제체 변위는 점차 감소하여 약 3,000 분 이후에는 거의 수렴하는 경향을 나타냈으나, 향후 관리수위 조건에서는 480 분에서 840 분까 지 제체의 변위가 급격하게 변화되는 경향을 나타냈다. 특히 향후 관리수위 조건에서 480 분과 840 분 사이의 제체 변위량 은 총 $2.1 \mathrm{~mm}$ 로 전체 제체 변위량 중 $47 \%$ 에 해당하는 변 위가 발생하였는데, 이는 향후 관리수위 조건에서의 동수경 사가 토립자의 이동을 발생시키는 한계동수경사 $\left(i_{c r}\right)$ 를 상회 하였기 때문으로 판단되며, 이로 인해 준설해사 내 미세 토 립자가 바닥보호공내 유로를 통해 갑작스런 이동이 발생한 것으로 판단되었다. 또한 향후 관리수위 조건에서의 제체 변 위량은 현재수위 조건에서의 제체 변위량보다 약 1.6 배 크게 발생하는 것으로 보아 수위 경계 변화에 따라서 제체의 변 위가 큰 차이를 보이는 것을 파악할 수 있었으며 이는 동수 경사의 증가가 제체의 변위에 큰 영향을 미치고 있는 것으 로 판단되었다.

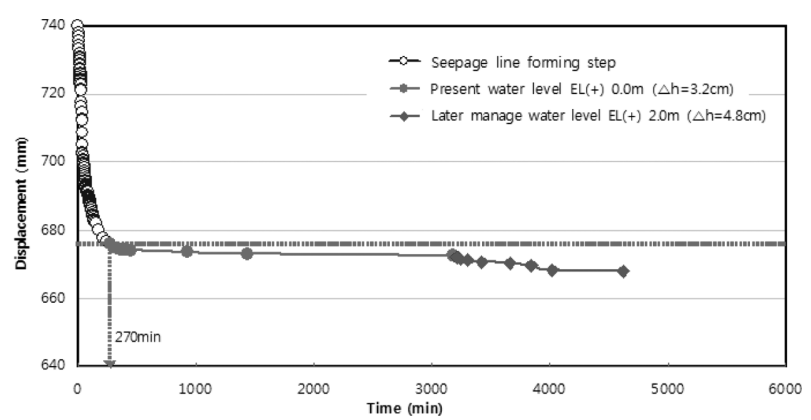

Fig. 13. Accumulated displacement of water level boundary variation. 


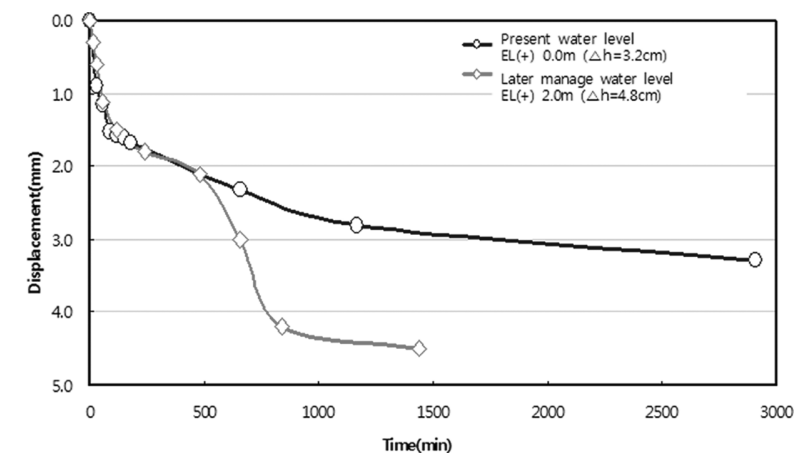

Fig. 14. Displacement of water level condition.

\subsection{2 동수경사의 증가에 따른 방조제의 제체 변형}

동수경사 조건별로 제체의 변위와 유실량을 측정한 결과, 제체의 변위는 완만하게 증가한 반면, 유실량은 동수경사가 작은 초기 단계에서 증가하는 경향을 띄었으나 그 크기는 무 시할 정도로 미세하게 나타났다. 반면에 수두차 $(\Delta \mathrm{h})$ 가 $1.5 \mathrm{~cm}$, 동수경사가 0.015 이후부터는 준설해사의 유실량이 급격히 증 가되었는데, 동수경사가 0.040 일 때 유실량은 $5,150 \mathrm{~cm}^{3}$ 로 동 수경사 0.015 일 때의 유실량은 $1,750 \mathrm{~cm}^{3}$ 보다 약 2.94 배 증 가하였다.

Fig. 15와 Fig. 16은 동수경사에 따른 변위량과 유실량을 측정한 결과이다. 제체의 변위는 동수경사의 증가에도 불구 하고 전 구간에 걸쳐서 거의 유사한 형태를 보였으나 유실 토 사량은 동수경사별로 큰 차이를 나타냈다. 특히 수두차가 $\mathrm{h}=\Delta 1.5 \mathrm{~cm}$ 일 때 유실 토사량은 수두차가 $\Delta \mathrm{h}=1.0 \mathrm{~cm}$ 보다 약 2 배가량 증가하였으며, 사석층과 토사층의 경계면에서 침 강된 미세 토립자가 사석층의 유로를 통하여 외부로 급속히 이동하는 현상도 육안으로 관찰 할 수 있었다. 따라서 사석 층에 충전된 준설해사의 유실을 발생시키는 수두차는 약

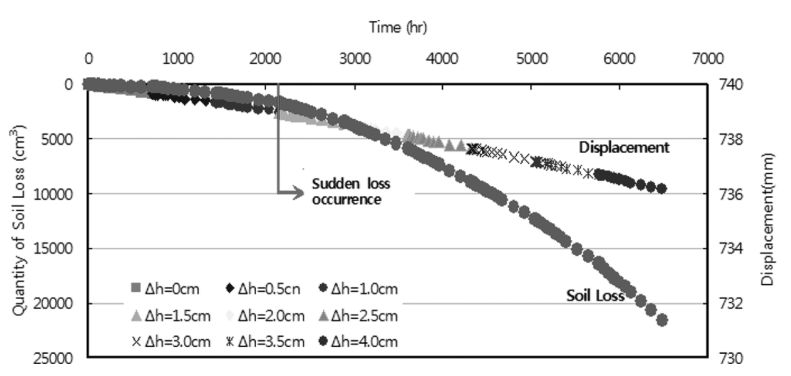

Fig. 15. Accumulated displacement $\&$ loss of hydraulic gradient.

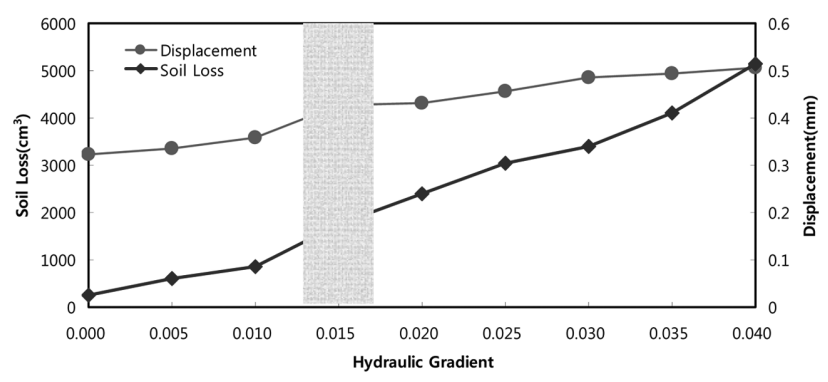

Fig. 16. Displacement \& loss of hydraulic gradient.

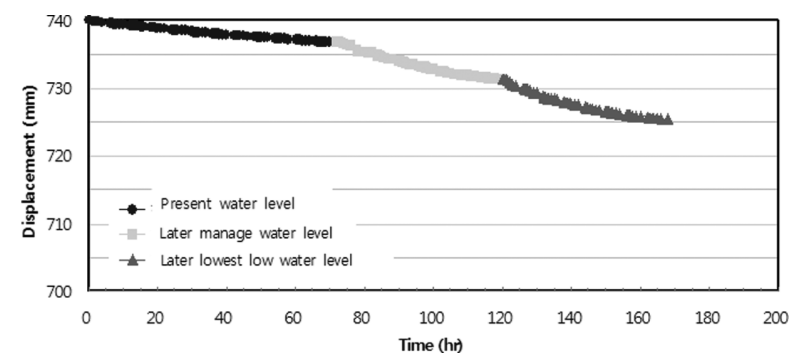

Fig. 17. Accumulated displacement of control water level.

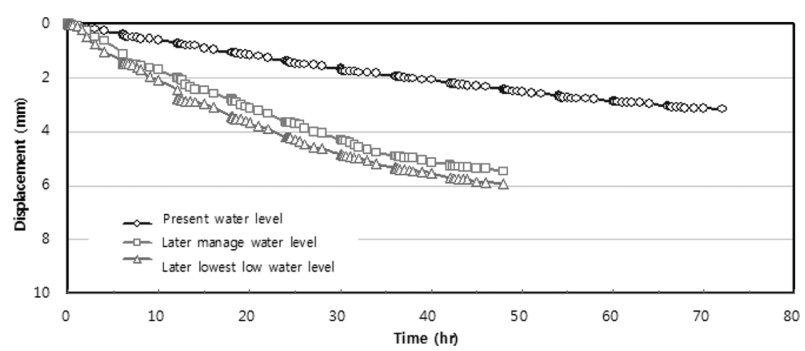

Fig. 18. Embankment behavior characteristics of control water level.

$1.5 \mathrm{~cm}$ 이며, 한계동수경사는 $\left(i_{c r}\right) 0.015$ 로 판단할 수 있었 으며, 제체의 동수경사가 한계동수경사를 상회할 경우, 제체 의 변위 및 토사의 유실량도 더욱 증가하여 제체의 안정성에 큰 영향을 미칠 것으로 판단되었다.

4.2.3 조위차와 내측 수위변화를 고려한 방조제 제체변형 조위변화를 6 시간 간격으로 만조위시 $($ 외측 $\mathrm{EL} .=3.2 \mathrm{~cm}$ )와 간조위시 $($ 외측 $\mathrm{EL} .=-4.0 \mathrm{~cm}$ )로 지속적으로 변화시키면서 현 재수위, 향후 관리수위, 향후 최저수위 조건별로 제체 변위가 수렴할 때까지 측정한 결과, 시간에 따른 변위는 현재수위 < 향 후 관리수위 <향후 최저수위(갈수위 고려)로 갈수록 증가하 는 것으로 나타났다.

Fig. 17에 조위변화 시 관리수위에 따른 누적 변위량을 시 간에 따라 나타냈으며, 약 7일간의 실험을 수행한 결과, 총 변위량은 $14.557 \mathrm{~mm}$ 로 조위변동에 따라 지속적인 유로가 형 성된 상태에서 수두차가 증가할 경우 제체의 변위가 더욱 크 게 나타날 것으로 판단되었다.

Fig. 18은 조위차를 고려한 관리수위별 시간에 따른 변위 량 형태를 나타낸 결과이다. 현재수위시 제체의 변위는 향후 관리수위와 향후 최저수위(갈수위 고려)의 변위량과 비교하 였을 때 초기단계에서 많은 변위가 발생하기보다 시간에 경 과함에 따라 변위량이 점차 감소하는 경향을 보였다. 반면에 향후 관리수위와 향후 최저수위 조건에서는 전체적으로 변위 량이 급격히 증가하다가 경과시간 40시간 무렵에 빠르게 수 렴하는 것을 확인할 수 있었다.

\section{3 침투모형시험에 대한 제체변형해석}

방조제의 안정성 평가를 위한 적절한 방법 검토를 위해서 침투모형시험에 대해서 유한요소법을 이용한 상용프로그램 인 SEEP/W를 사용하여 수치해석을 수행하였다. 수치해석시 


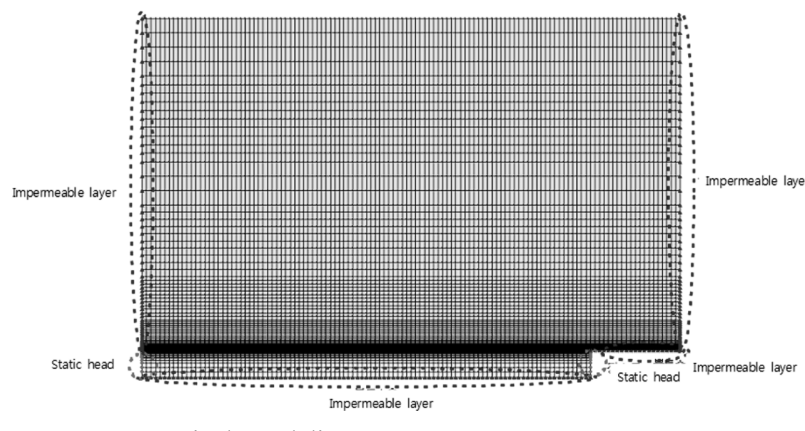

Fig. 19. Numerical Modeling.

적용된 입력정수는 변수위 시험결과인 사석은 $1.0 \mathrm{~cm} / \mathrm{sec}$, 준 설해사는 $6.08 \times 10^{-4} \mathrm{~cm} / \mathrm{sec}$ 를 적용하였다. 경계조건은 12 시 간 간격으로 $0 \sim 108$ 시간 동안에 내측높이 E.L $0.0 \mathrm{~cm}$ 를 기 준으로 외측높이를 $\Delta \mathrm{h}=0.5 \mathrm{~cm}$ 씩 증가시켜 $4.0 \mathrm{~cm}$ 까지 Step 1에서 Step 9까지 동수경사를 0.005 씩 증가시켜 0 에서 0.040 까지 경계조건을 설정하였고, 권·한(2006)이 분할요소 의 높이가 제방높이의 $1 / 10$ 이하가 되면 제체 선단의 국소 동수경사는 크게 변하지는 않고, $1 / 20$ 이하에서는 거의 일 정한 값으로 수렴하므로 $1 / 20$ 이하를 제시한 바 있어, 이를 고려하여 본 연구에서는 최대 요소크기를 $3.2 \mathrm{~cm}$, 바닥보호 공은 $0.2 \mathrm{~mm}$ 로 이산화하여 최상의 결과가 도출될 수 있도 록 하였다. Fig. 19에 침투모형시험에 대한 수치해석 단면을 나타내었다.

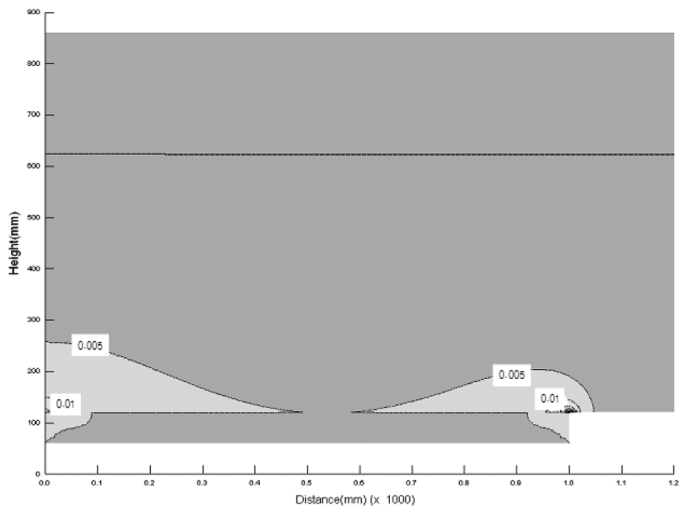

(a) Step 2

Fig. 20. Loss possibility area (Method of critical hydraulic gradient).

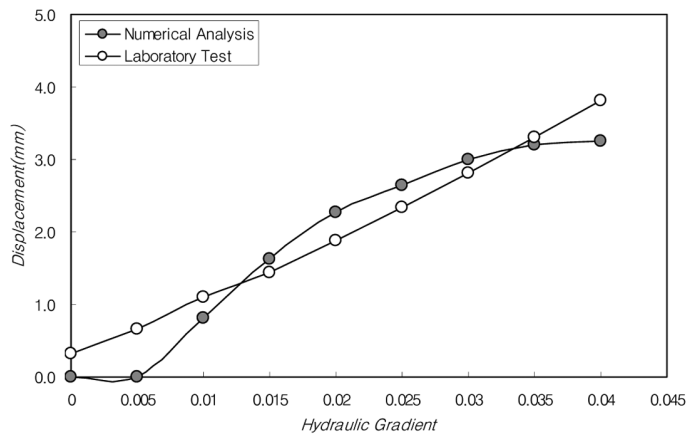

(a) Displacement

\subsection{1 한계동수구배를 이용하는 방법}

파이핑 안정성에서 가장 일반적으로 이용되는 방법이 한계 동수경사를 이용한 방법이다. 본 연구에서 한계동수경사는 여 러 가지 방법에 의해 산정된 최소 한계동수경사 0.30 과 실내 시험에서 급격한 유실량을 보였던 동수경사 0.015 를 모두 적 용하였다. 그러나 모든 조건이 기존문헌에서의 한계동수경사 보다 작은 조건에서 수행되었고, 이때 유실이 발생하였음을 알 수 있었다. 또한, 실내시험에서 결정된 0.015 를 적용하여 보았지만, 0.015 보다 외부 동수경사가 더 클 경우 시료 내부 모든 영역에서 한계동수경사를 넘어서는 것으로 나타났다. 따 라서 본 방법은 적용하는 것이 어렵다고 판단되었다. Fig. 20 에 Step 2와 Step 9에 대한 결과를 나타내었다.

\subsection{2 한계유속에 의한 방법}

한계유속에 의한 방법은 침투해석 결과로부터 산정된 유출 유속(discharge velocity)과 이로부터 결정된 침투유속(seepage velocity)을 사용된 시료의 입경에 따른 한계유속과 비교하여 해석상의 침투유속이 한계유속 이상이 되는 영역을 토립자의 유실 가능성이 높은 영역으로 고려하여 최종 변형량을 추정 하는 방법이다.

본 방법으로 해석한 결과 최소의 한계유속(침투유속 $=0.0064$ $\mathrm{cm} / \mathrm{sec}$, 유출유속 $=0.0021 \mathrm{~cm} / \mathrm{sec}$ )을 적용한 결과, 대부분의 조건에서 한계유속을 초과하는 영역은 매우 미소한 것으로 나

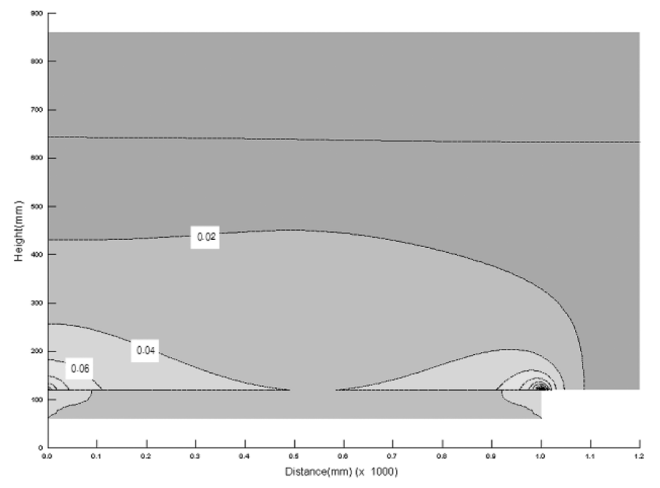

(b) Step 9

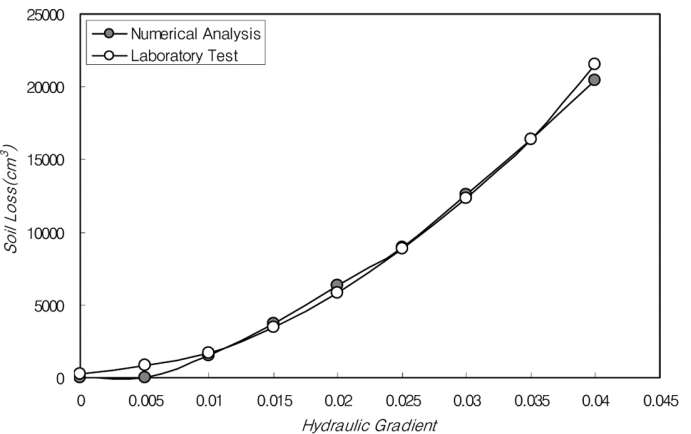

(b) Loss

Fig. 21. Revised displacement and loss (Method of critical velocity of flow). 


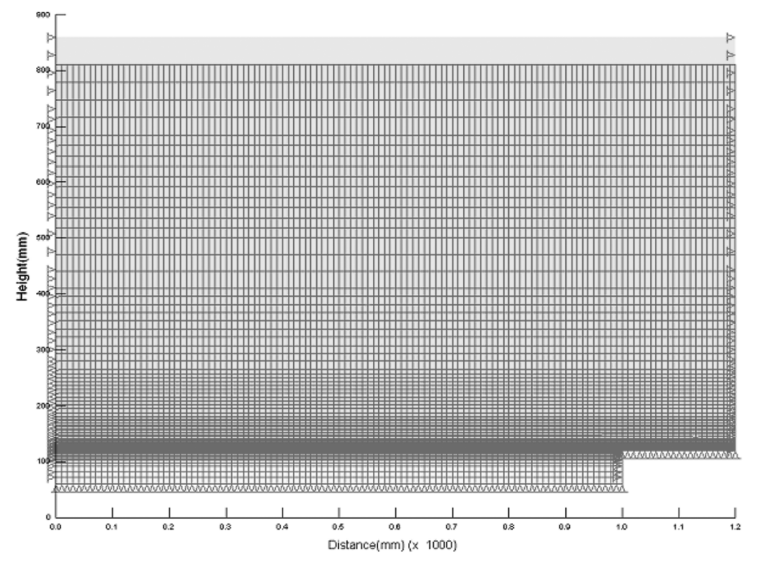

(a) Deformed shape

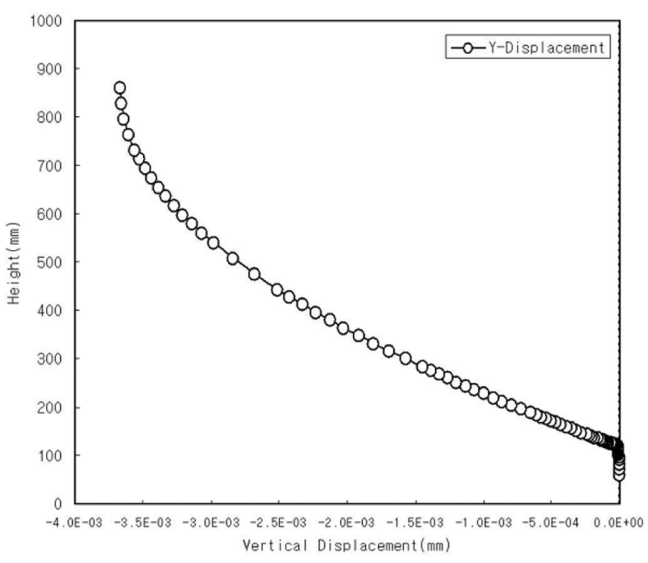

(b) Vertical displacement

Fig. 22. Stress-Deformation analysis (Step 2).

타났다. 하지만 수치해석 기법에서 불규칙적인 유로형성 조건, 파이핑 발생시 급격한 유속증가를 묘사하는 것은 한계 가 있는 것으로 판단되었다.

따라서 실제 바닥보호공에서 유속을 측정한 결과를 분석해 보면 평균유속이 $0.039 \mathrm{~m} / \mathrm{sec}$ (와류구간 평균 $0.08 \mathrm{~m} / \mathrm{sec}$ )로 준설해사 입경 $(0.1 \mathrm{~mm}$ 기준 $)$ 한계유속이 $0.008 \sim 0.03 \mathrm{~m} / \mathrm{sec}$ 로 측정유속이 한계유속보다 상회하는 상태로 향후 수위변화가 발생하면 동수구배의 증가로 현 측정유속보다는 더 큰 유속 이 발생할 것으로 판단되었다.

수치해석상의 유실 가능영역 및 변위량이 실측된 값보다 작 게 나타나는 이유는 유효입경으로 산정된 한계유속이 실제 유 실될 수 있는 침투유속보다 컸기 때문이다. 따라서 해석상의 변 위 및 유실량과 실측된 변위 및 유실량의 비를 비교하였다. 비교한 결과 측정된 값과 해석된 값 사이에는 상관성이 높은 지수함수적 관계가 성립됨을 알 수 있었다. 따라서 수치해석 상의 유실량 및 이로부터 추정된 변위량은 각 동수경사에 따 라 보정하여 적용한다면 향후 실제 단면에 대해서도 적용 가 능할 것으로 판단되었다. Fig. 21은 보정계수를 적용하여 재 산정된 변위량과 유실량을 실측된 값과 최종 비교하여 제시 한 것으로, 실측값과 해석값이 잘 일치하는 것으로 나타났다.

\subsection{3 유한요소 연계해석에 의한 방법}

실내시험 결과 유실량과 지표 변위와는 일대일 대응관계가 성립하지 않았으며, 동수경사가 증가할수록 유실량과 지표 변 위로부터 역산한 유실량의 비는 증가하는 것으로 나타났다. 따라서 수치해석을 통한 지반 변위를 산정하기 위해 변형 해 석이 가능한 프로그램과 침투해석 결과를 연계하여 해석하 였다. 본 연구에서는 비정상상태 침투해석과 그 결과를 이용 한 응력-변형 해석이 가능한 SEEP/W와 SIGMA/W 연계해 석을 실시하였다.

Fig. 22는 동수경사 0.005 에서의 해석 결과로 변위는 하향 으로 거의 균등한 변형 형태를 보였으며, 최대 변위량은 $0.004 \mathrm{~mm}$ 로 매우 미소한 값을 나타내었다. 이는 초기 침윤
선 형성단계 이후 동수경사, 0.005 로 수위가 변화할 때, 유효 응력의 변화가 매우 미비하기 때문에 유효응력의 변화량에 비 례하는 변위가 작게 나타난 것이다. 따라서 본 방법으로 침 투유실에 따른 변위와 유실량을 정량적으로 산정하는 것은 어 려울 것으로 판단되었다.

\section{5. 결 론}

본 연구에서는 침투변화에 따른 방조제의 안정성을 파악하 기 위하여 현장조사를 통해서 바닥보호공내에 준설해사 충전 현황을 파악하였으며, 이를 바탕으로 방조제의 사석재료 및 근고공, 바닥보호공에 대한 투수계수와 시공과정에서의 형상 변화를 역해석 방법으로 결정하였다. 또한 침투모형시험으로 제체의 변형량과 토사 유실량을 측정하고, 사석층 내의 토사 충전여부를 파악하여 제체의 안정성을 검토하기 위하여 침투 모형시험을 3 가지 조건으로 진행하였다. 또한 현재까지 침투 유실과 그에 따른 지표 변위량을 정량적으로 해석할 수 있는 해석기법이 개발되지 않아 상용 프로그램을 이용하여 실내에 서 수행된 침투모형시험에 대해 가장 합리적인 수치해석(침 투해석)방법을 제안하였다.

(1) 현장조사 및 침투계측 결과 방조제는 바닥보호공 상부 로 준설해사가 축조되어 있는 다층지반 침투 구조물이며 다 층지반의 투수계수의 차에 의해 바닥보호공과 성토체 경계부 부근에서 유실영역이 발생하였다. 이러한 유실은 준설해사가 바닥보호공 사석의 공극 사이로 충전되는 것으로 유실되는 만 큼의 준설 성토체의 변형이 발생한다는 것을 예측할 수 있 었다.

(2) 수위경계 변화에 따른 제체변형의 침투모형시험 결과 침윤선 형성이 완료된 이후에 향후 관리수위 조건에서의 제 체 변형량은 현재수위 조건에서의 제체 변형량보다 크게 발 생하였고, 이는 동수경사의 증가가 제체의 변형에 큰 영향을 미치고 있기 때문인 것으로 판단되었다.

(3) 동수경사의 증가에 따른 방조제 제체변형에 대한 침투 
모형시험 결과 제체의 변위는 동수경사의 증가에도 불구하고 전 구간에 걸쳐 거의 유사한 형태로 완만하게 증가한 반면, 준설해사의 유실량은 한계 동수경사 이후부터는 급격히 증가 하였다. 이는 제체의 동수경사가 한계동수경사를 상회할 경우, 제체의 변위 및 토사의 유실도 더욱 증가하여 제체의 안정성에 큰 영향을 미치는 것을 예상할 수 있었다.

(4) 조위차와 내측 수위변화를 고려한 방조제 제체변형에 대한 침투모형시험 결과 조위변화는 방조제의 제체변형에 영 향을 미쳤다. 즉 방조제 제체 변형은 현재수위 <향후 관리수 위<향후 최저수위로 갈수록 증가하였다.

(5) 침투모형시험에 대한 수치해석 결과 한계동수경사를 이 용하는 방법은 실험에서의 동수경사가 모두 작아서 유실이 발 생하지 않거나 시료 내부의 모든 영역에서 한계동수경사를 넘 어서 모든 영역이 유실 가능한 영역으로 산정되는 문제점을 보였고, 유한요소 연계해석방법은 유효응력의 변화가 매우 작 아서 변형량이 미비하게 예측되어 실내 침투모형시험결과와 일치하지 않는 결과를 보였다. 한계유속을 이용하는 방법은 침투모형시험에서 측정된 유실량과 지표변위가 침투해석에서 구한 값보다 작게 나타났으나 그 경향이 일치하여, 보정계수 를 이용하여 보정하면 방조제 실제단면에서도 적용가능할 것 으로 판단되었다.

\section{참고문헌}

건설교통부 (2005). 댐 설계기준.

권교근 (2006). 우리나라 하천제방에 대한 내부침식 파괴 연구. 대한토목학회, 26(1C), 33-42.

농림수산부, 농어촌진흥공사 (1990). 새만금지구 방조제 단면 및 기초처리에 관한 설계검토.

오남선 (1997). 방조제의 Piping에 대한 안정성 검토. 목포해양 대학교 논문집 5(II), 281-291.

정신택 (2002). 비정상 상태의 방조제 침투해석. 원광대학교 공
업기술개발연구소, 22, 30-34.

최흥식 (2004). 호안제체에서 Non-Darcy 흐름해석. 한국수자원 학회논문집, 37(2), 96-97.

한국농촌공사, 농어촌연구원 (2005). 방조제 파이핑 방지 및 대 책공법 연구 I.

한국농촌공사, 농어촌연구원 (2006). 방조제 파이핑 방지 및 대 책공법 연구 II.

허재은 (1996). 방조제의 소성침하예측 및 파이핑의 해석. 석사 학위논문, 전남대학교 대학원, 115-117.

Hansen, D. (1992). The Behaviour of Flow Through Dams, Ph.D. Thesis. Thesis, Dept. of Civil Eng. Univ. of Ottawa, Ottawa, Canada.

Kalin, M. (1977). Hydraulic Piping-Theoretical and Experimental Findings. Canadian Geotechnical Journal, 14(1), 107-124.

Kovacs, G. (1981). Seepage Hydraulics. Elservier Scientific Publishing Co., 349-362.

Richardson, J.F. and R.A. Meikle (1961). Sedimentation and Rluidization III. Trans. Int. Chem. Engrgs., 39(5), pp. 348.

Schmertmann, J. H. (2000). The No-Filter Factor of Safety against Piping through Sands. ASCE, Geotechnical Special Publication No.111, 65-133.

Stephenson, D. (1979). Rockfill in Hydraulic Engineering, Elsevier Science Publishers BV (North-Holland). Amsterdam, The Netherlands, 19-24.

Sughii, T. O., Sato, D., Woono, D. O. and Yamada, S. G. (1989). Process of Seepage Failure and Effect of Heterogeneity in Soil(Japanese), Soil and Foundation, 6, 17-22

Terzaghi, K. (1943). Theoretical Soil Mechanic, John Wiley and sons Inc, New York.

원고접수일: 2012년 3월 26일

수정본채택: 2012년 6월 13일 (1차)

수정본채택: 2012년 7월 9일 (2차)

게재확정일: 2012년 7월 13일 